TITLE:

\title{
Rhodolith Bed Composition in the Southwestern Gulf of California, Mexico
}

$\operatorname{AUTHOR}(S):$

YABUR-PACHECO, RICARDO; RIOSMENARODRIGUEZ, RAFAEL

\section{CITATION:}

YABUR-PACHECO, RICARDO ... [et al]. Rhodolith Bed Composition in the Southwestern Gulf of California, Mexico. Publications of the Seto Marine Biological Laboratory. Special Publication Series 2007, 8: 37-47

\section{ISSUE DATE:}

2007

URL:

http://hdl.handle.net/2433/70912

RIGHT: 


\title{
Rhodolith Bed Composition in the Southwestern Gulf of California, México
}

\author{
Ricardo Yabur-Pacheco and Rafael Riosmena-RodrigueZ* \\ Departamento de Biologia Marina, Universidad Autonoma de Baja California Sur (UABCS) \\ Carretera al sur Km. 5.5, La Paz B. C. S. CP. 23080, Mexico \\ Corresponding author's e-mail: riosmena@uabcs.mx
}

\begin{abstract}
The composition of rhodolith beds, relative abundance of species and growth-forms, was evaluated in relation to a depth gradient and substratum along the southwestern Gulf of California. Replicate transects were established in twelve rhodolith beds to evaluate the species and growth form distribution in relation to depth (2-7, 7-12 and 12-20 m) and habitat (sand vs. rock). Four species with four growth-forms were determined: Lithophyllum margaritae which ranged in growth-form from fruticose, fructifoliose to foliose; Lithothamnion muelleri where the growthform range was lumpy to fruticose; in both Neogoniolithon trichotomum and Mesophyllum engelhartii where only fruticose growth-form was observed. Lithophyllum margaritae was the most abundant species in relation to depth in the sandy habitat and Lithothamnion muelleri was dominant in the shallow rocky areas. The presence of $N$. trichotomum was limited to shallow sandy beds and $M$. engelhartii was limited to the deeper areas. Growth-forms also showed a variation with depth and substrata, in where fruticose forms dominate in sandy areas, lumpy forms dominate in rocky habitats and foliose forms were more abundant in the deeper areas. The differences in the abundance of each species and growth form might be explained by a combination of biological features; growth rate, density of reproductive structures and calcification rate in relation to environmental features such substrate type (rock vs. sand), water motion and light.
\end{abstract}

Key words: Rhodolith beds, Growth-forms, Lithophyllum, Lithothamnion, Neogoniolithon, Mesophyllum

\section{Introduction}

Rhodolith beds are widely distributed, forming extensive communities of free-living coralline algae in a wide range of depths (Foster, 2001). They are known to collectively create a fragile, structured biogenic matrix (Foster et al., 1997). This matrix provides habitat for diverse assemblages of invertebrates and algae (Cabioch, 1969; Keegan, 1974; Steller et al., 2003). Rhodolith beds are one of the major nearshore biogenic sediment producers (Mabesone et al., 1972; Wilson and Bosence, 2003), and are useful for the interpretation of distinct paleo-environments (Carannante et al., 1988; Freiwald et al., 1991; Foster et al., 1997; Basso, 1998).

Rhodoliths have a wide bathymetrical and geographical distribution (review by Foster, 2001), but very little is known about the species composition of the beds on ecological or geographical scales. Individual rhodoliths might be formed by a single species (Payri, 1997; Riosmena-Rodríguez et al., 1999) or a group of species (Basso, 1998). In turn rhodolith beds can be composed of a single dominant species ex. Hydrolithon reinboldii (Payri, 1997) or a combination of several dominate species such as Lithothamnion corallioides and Phymatolithon calcareum and Lithothamnion glaciale in Scotland (Birkett et al., 1995). The proportions in which these species are present vary both spatially and temporally (Birkett et al., 1995), although no specific evaluation has been made in relation to environmental conditions. It is commonly found that fruticose growth-form are most common form shallow water beds (Kempf, 1970; Adey and McKibbin, 1970; Bosence, 1985; Piller and Rasser, 1996) and foliose forms in deep water beds although this has not been intentionally 
evaluated. Studies have suggested that species and growth form composition are variable, and these variations have been attributed to distinct environment conditions (Blunden et al., 1977; Bosence, 1983; Steller and Foster, 1995). In many areas the species composition of beds is compromised due to the poor taxonomic status of the species involved.

In the Gulf of California, Steller and Foster (1995) have shown that rhodolith morphology is related to a depth gradient. Foster et al. (1997) described that beds are organized in two environments (wave and current beds) linked with depth and water motion; also the beds are distributed in two substrates sandy and rocky-sandy areas, where blunt morphologies dominate in exposed areas with high wave action. Steller et al. (2003) suggested that beds are composed of three species (Neogoniolithon trichotomum, Lithothamnion muelleri and Lithophyllum margaritae) and dominated by L. margaritae. These conclusions were based on limited spatial and geographical sampling and no growth-form evaluation was presented.

The aims of this study are to: 1) describe the species and growth-form composition of the beds in the southwestern Gulf of California, México; 2) determine if there is any relationship of species and growth-form composition with depth, substrate and/or geographic distribution.

\section{Material and Methods}

To understand the species and growth form composition of rhodolith beds, 12 beds occurring between Santa Rosalia to Los Cabos were selected. The beds were chosen to represent different depths $(2-7,7-12,12-20)$, type of bed (current vs. wave), habitat (only sandy vs. mixture of sand-rock) and geographical location (north vs. south). All the selected beds are described in RiosmenaRodriguez et al. (2006, Fig. 2, Table 1). At each site two unrelated random 50m transects were laid out along the sea floor at the planned depth. The first 50 intercepted plants, bigger than $2 \mathrm{~cm}$ diameter, with good purple-pink coloration, were collected, from both transects.

The samples were dried in the shade and determined to species level based on RiosmenaRodríguez et al. (2006, Figs 3-5, Table 1). After this, each species was classified into growth-forms in accordance with Woelkerling et al. (1993). The mean of the relative abundance was measured as the proportion of each species and growth-form were clumped at each treatment (depth, substrate type, wave-current and habitat) and calculated (Table 2). Statistically significant differences in the species and growth-forms were assessed with ANOVA and Kruskall-Wallis tests. Tukey and Nemenyi's tests (Zar, 1996) were used to find a posteriori groups of means that differed significantly.

\section{Results}

The rhodolith beds are generally dominated by the species Lithophyllum margaritae and fruticose is the most common growth form (Table 2, Figs 1-3). Lithophyllum margaritae and Lithothamnion muelleri have the widest range of growth forms and depth distribution present in the area (Table 2, Figs 1- 4). A clear trend was observed in relation to depth in where L. margaritae was the dominant among the 3 species present in all depths (Figs $1-3$ ), with significant differences among species at the two lower depths (Figs 2.3; $p=0.05$ ) and no significant difference between species (Fig. 1). Neogoniolithon trichotomum was only present in the shallow depth $(2-7 \mathrm{~m})$; Mesophyllum engelhartii was only present in the deeper areas (over $20 \mathrm{~m}$ ), and the proportion of $L$. muelleri was greater in the shallow $(2-7 \mathrm{~m})$ and middle regions than the deeper areas (20m, Fig. 1).

The three growth-forms identified in the samples of Lithophyllum margaritae were found in all depths although there was variation in the proportions found between depths (Figs 4-6). The proportion of the fruticose form was consistent between $2-7$ and 7-12m but significantly different than 
Table 1. Principal features of each of the sampling localities. Depth, type of bed and main substrate are presented using the number used in Riosmena-Rodriguez et al., (2007).

\begin{tabular}{lcccc}
\hline Locality & $\begin{array}{c}\text { Sampling } \\
\text { depth } \\
(\mathbf{m})\end{array}$ & Type of bed & $\begin{array}{c}\text { Main } \\
\text { Substrate }\end{array}$ & $\begin{array}{c}\text { Bed number in Figure 1 } \\
\text { of Riosmena- Rodriguez } \\
\text { et al. (2006) }\end{array}$ \\
\hline 1. Cardón & $2-7,7-12$ & Wave & Sandy & 26 \\
2. Requesón & $2-7,7-12$ & Wave & Sandy & 27 \\
3. Pocitos & $2-7,7-12$ & Wave & Sandy & 29 \\
4. Coloradito & $2-7,7-12$ & Wave & Sandy & 30 \\
5. Coronado I & $7-12$ & Wave & Sandy & 32 \\
6. Coronado II & $12-20$ & Current & Sandy & 33 \\
7. Diguet & $12-20$ & Current & Sandy & 42 \\
8. Diana & $12-20$ & Current & Sandy & 44 \\
9. San Francisco & $12-20$ & Current & Sandy & 45 \\
10. San Lorenzo & $12-20$ & Current & Sandy & 48 \\
11. Calerita & $2-7$ & Wave & Rock/sandy & 49 \\
12. Punta Perico & $12-20$ & Current & Rock/sandy & 53 \\
\hline
\end{tabular}

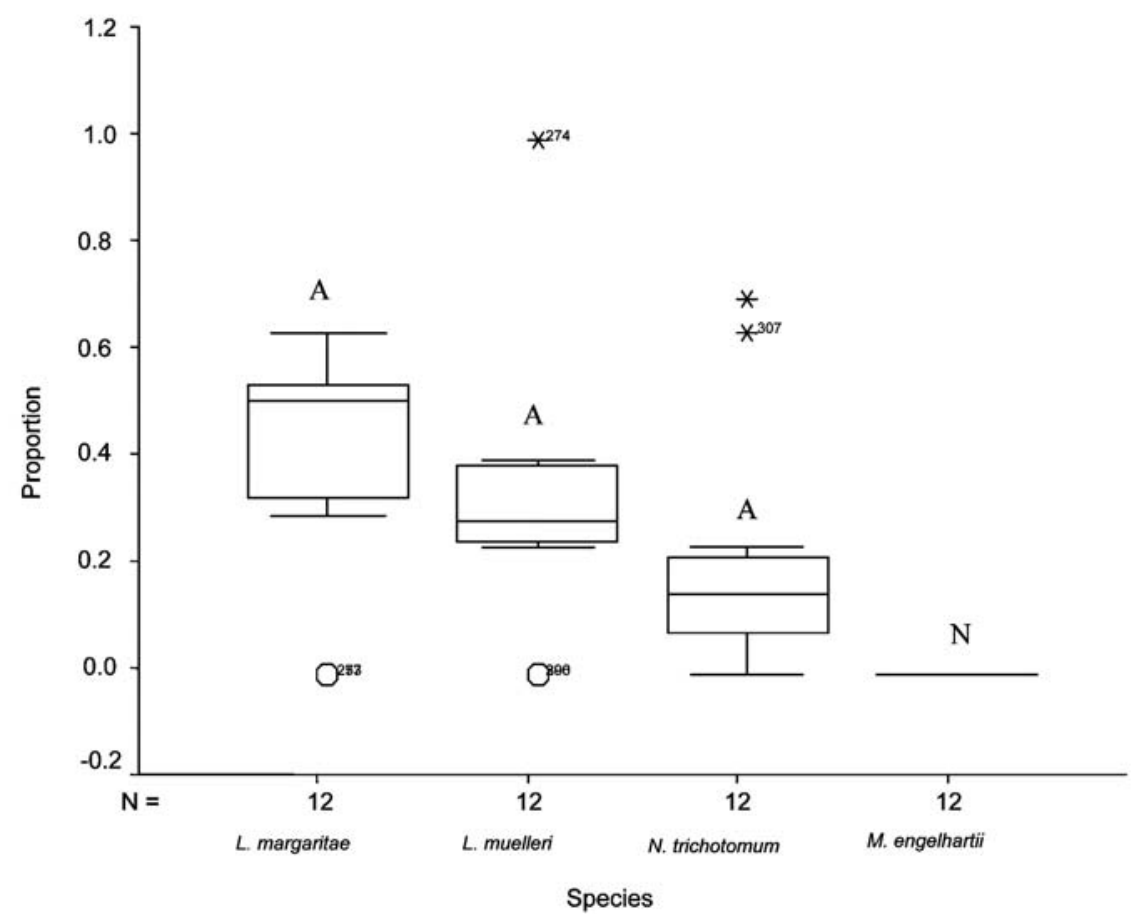

Fig. 1. Proportion of rhodolith bed forming species between $2-7 \mathrm{~m}$ depth. Box plots denoted by a different capital letter differ significantly by ANOVA test $(\mathrm{p} \leq 0.05)$ with post-hoc Tukey test, asterisks and circles represent the significant group. Bars represent standard deviation. 


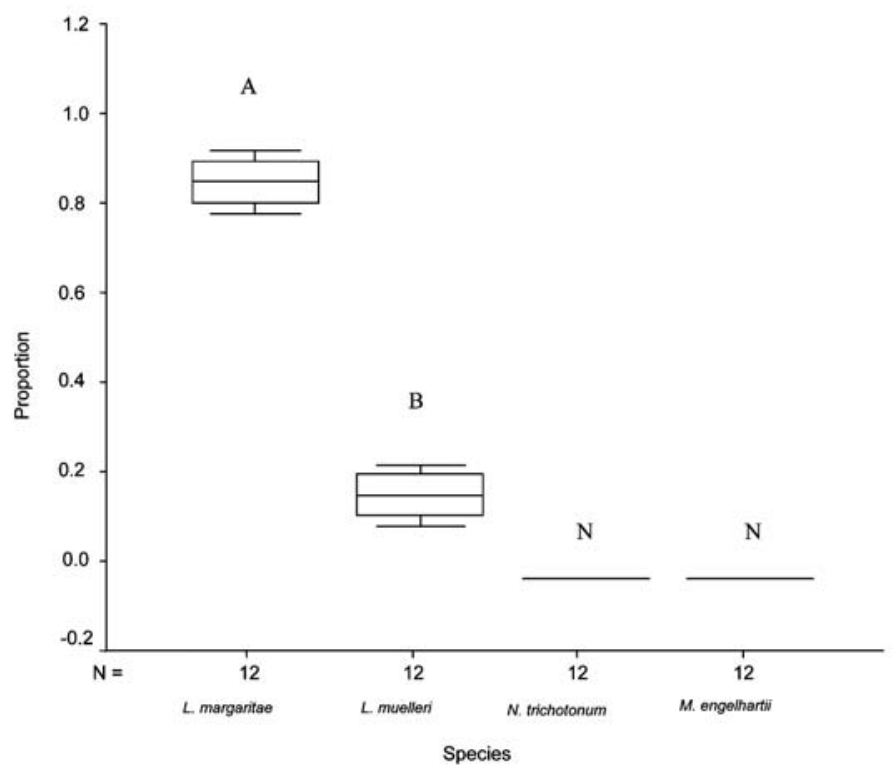

Fig. 2. Proportion of rhodolith bed forming species between 7-12m depth. Meaning of symbols and letters are the same as in Fig.1.

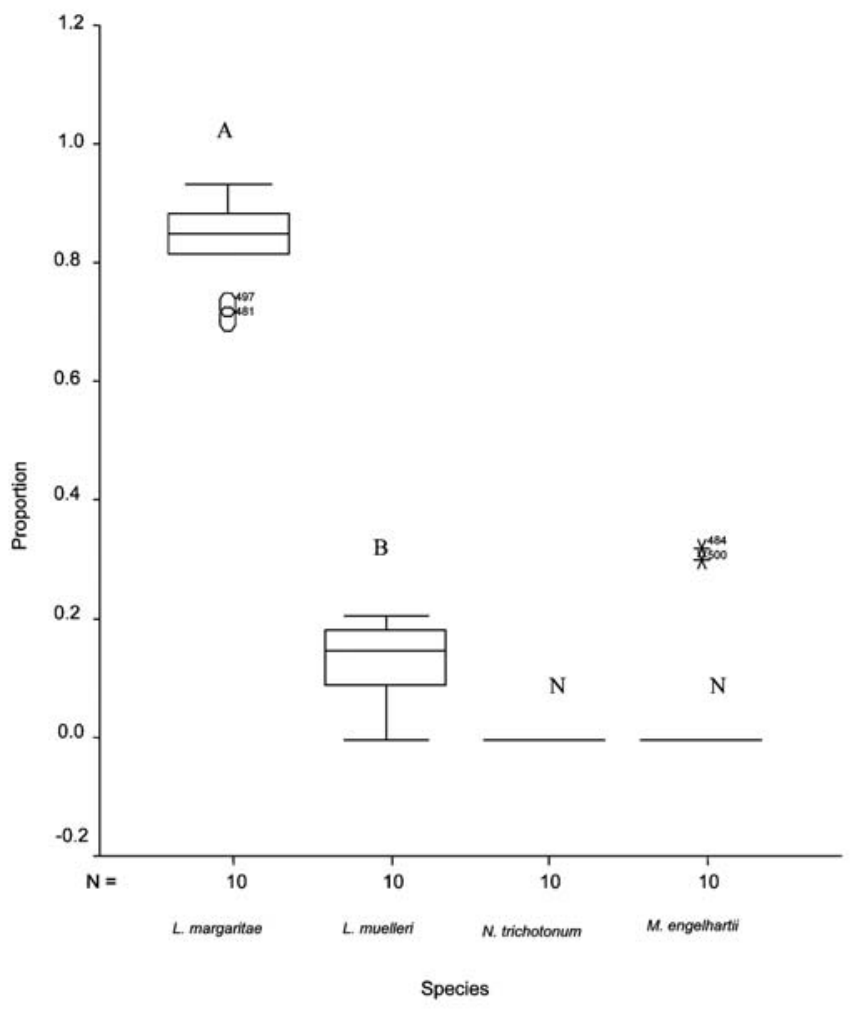

Fig. 3. Proportion of rhodolith bed forming species between $12-20 \mathrm{~m}$ depth. Meaning of symbols and letters are the same as in Fig.1. 


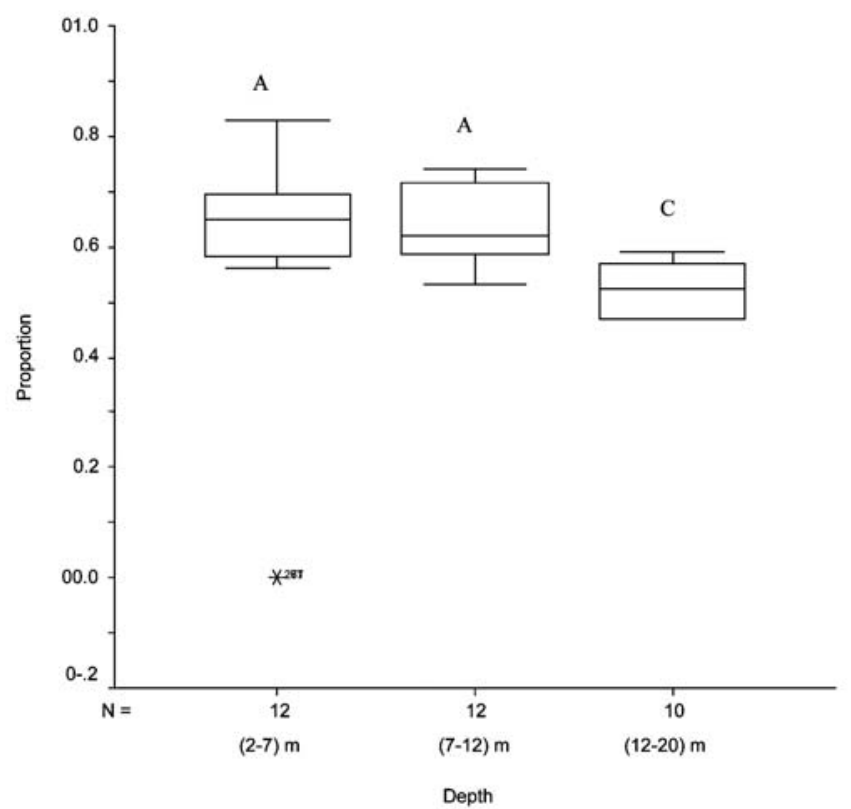

Fig. 4. Proportion of fructicose morphology of $L$. margaritae by depth. Box plots denoted by a different capital letter differ significantly by K-W test ( $\mathrm{p} \leq 0.05)$ with post-hoc Dunn. Bars represent standard deviation.

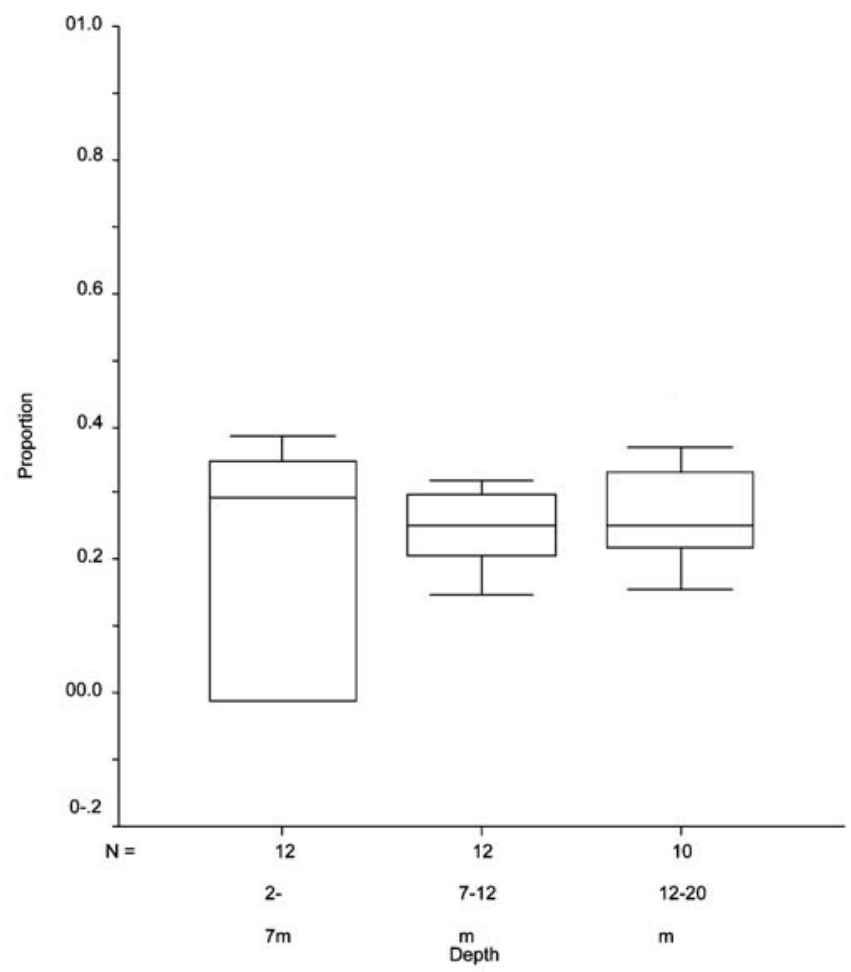

Fig. 5. Proportion of fructifoliose morphology of $L$. margaritae by depth. Meaning of symbols and letters are the same as in Fig.4. 
Table 2. Composition of the species and growth form in each environmental condition. Data are mean \pm standard deviation, $N P=$ Not present. The fist number shows the proportion of the growth morphologies for each species in the corresponding environment. The total number printed in bold, shows the proportion of each species at various environmental conditions.

\begin{tabular}{|c|c|c|c|c|c|c|c|c|}
\hline \multirow[t]{2}{*}{ Specie } & \multirow[t]{2}{*}{$\begin{array}{l}\text { Growth- } \\
\text { form }\end{array}$} & \multicolumn{3}{|c|}{ Depth } & \multicolumn{2}{|c|}{ Substratum } & \multicolumn{2}{|c|}{ Bed type } \\
\hline & & 2-7 m & $7-12 \mathrm{~m}$ & $12-20 \mathrm{~m}$ & Sand & Rock & Wave & Current \\
\hline & & $\mathrm{N}(12)$ & $\mathrm{N}(12)$ & $\mathrm{N}(10)$ & $\mathrm{N}(30)$ & $\mathrm{N}(4)$ & $\mathrm{N}(24)$ & $\mathrm{N}(10)$ \\
\hline \multirow{4}{*}{$\begin{array}{r}\text { L. margaritae } \\
(0.68 \pm 0.24)\end{array}$} & Fructicose & $0.56 \pm 0.27$ & $0.64 \pm 0.07$ & $0.52 \pm 0.05$ & $0.62 \pm 0.09$ & $0.25 \pm 0.29$ & $0.60 \pm 0.20$ & $0.52 \pm 0.05$ \\
\hline & Fructifoliose & $0.23 \pm 0.17$ & $0.26 \pm 0.06$ & $0.28 \pm 0.07$ & $0.27 \pm 0.10$ & $0.18 \pm 0.21$ & $0.24 \pm 0.13$ & $0.28 \pm 0.07$ \\
\hline & Foliose & $0.05 \pm 0.10$ & $0.11 \pm 0.05$ & $0.20 \pm 0.05$ & $0.12 \pm 0.10$ & $0.07 \pm 0.08$ & $0.08 \pm 0.08$ & $0.20 \pm 0.05$ \\
\hline & Total & $0.42 \pm 0.21$ & $0.84 \pm 0.04$ & $0.83 \pm 0.07$ & $0.73 \pm 0.18$ & $0.35 \pm 0.36$ & $0.63 \pm 0.26$ & $0.83 \pm 0.08$ \\
\hline \multirow{3}{*}{$\begin{array}{l}\text { L. muelleri } \\
\quad(0.22 \pm 0.22)\end{array}$} & Lumpy & $0.30 \pm 0.30$ & $0.04 \pm 0.10$ & $0.26 \pm 0.07$ & $0.15 \pm 0.17$ & $0.50 \pm .0 .57$ & $0.17 \pm 0.28$ & $0.26 \pm 0.22$ \\
\hline & Fructicose & $0.54 \pm 0.40$ & $0.96 \pm 0.10$ & $0.54 \pm 0.11$ & $0.78 \pm 0.27$ & $N P$ & $0.75 \pm 0.36$ & $0.54 \pm 0.33$ \\
\hline & Total & $0.37 \pm 0.31$ & $0.16 \pm 0.04$ & $0.11 \pm 0.07$ & $0.18 \pm 0.09$ & $0.50 \pm 0.57$ & $0.27 \pm 0.25$ & $0.11 \pm 0.07$ \\
\hline \multirow{2}{*}{$\begin{array}{r}N . \text { trichotonum } \\
(0.075 \pm 0.17)\end{array}$} & Fructicose & $0.83 \pm 0.38$ & $N P$ & $N P$ & $0.33 \pm 0.48$ & $N P$ & $0.42 \pm 0.50$ & $N P$ \\
\hline & Total & $0.21 \pm 0.22$ & $N P$ & $N P$ & $0.09 \pm 0.17$ & $N P$ & $0.11 \pm 0.19$ & $N P$ \\
\hline \multirow{3}{*}{$\begin{array}{r}\text { M. engelhartii } \\
\quad(0.018 \pm 0.07)\end{array}$} & Lumpy & $N P$ & $N P$ & $0.05 \pm 0.10$ & & $0.11 \pm 0.14$ & & $0.05 \pm 0.10$ \\
\hline & Fructicose & $N P$ & $N P$ & $0.15 \pm 0.32$ & $N P$ & $0.39 \pm 0.44$ & & $0.15 \pm 0.32$ \\
\hline & Total & $N P$ & $N P$ & $0.06 \pm 0.13$ & $N P$ & $0.15 \pm 0.18$ & $N P$ & $0.06 \pm 0.13$ \\
\hline
\end{tabular}

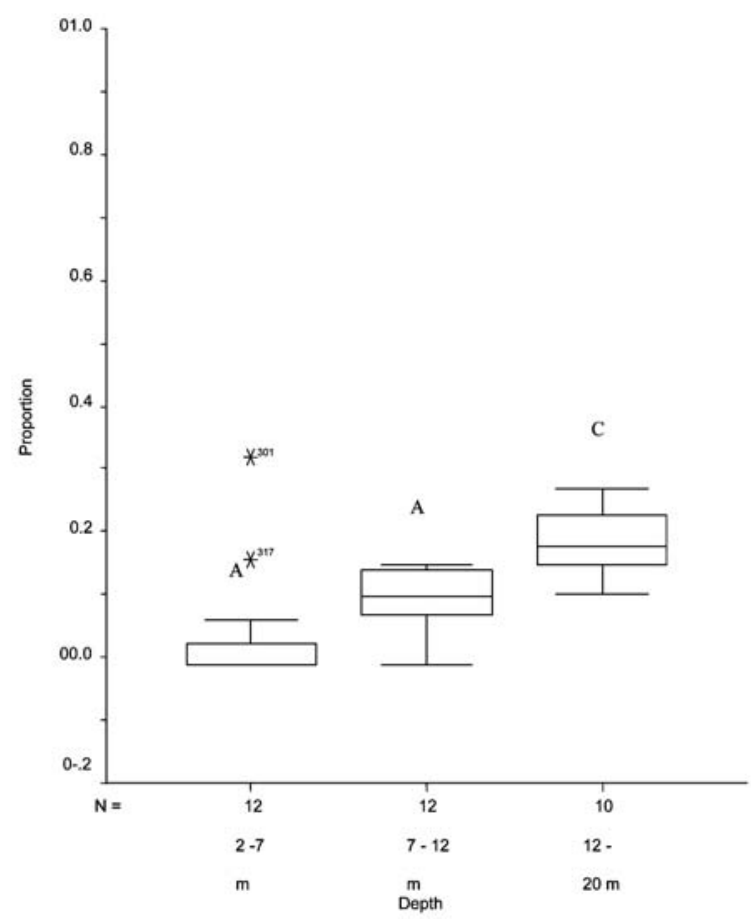

Fig. 6. Proportion of foliose morphology of $L$. margaritae by depth. Box plots denoted by a different capital letter differ significantly by K-W test ( $\mathrm{p} \leq 0.05$ ) with post-hoc Dunn Test, asterisks represents the significant group. Bars represent standard deviation. 


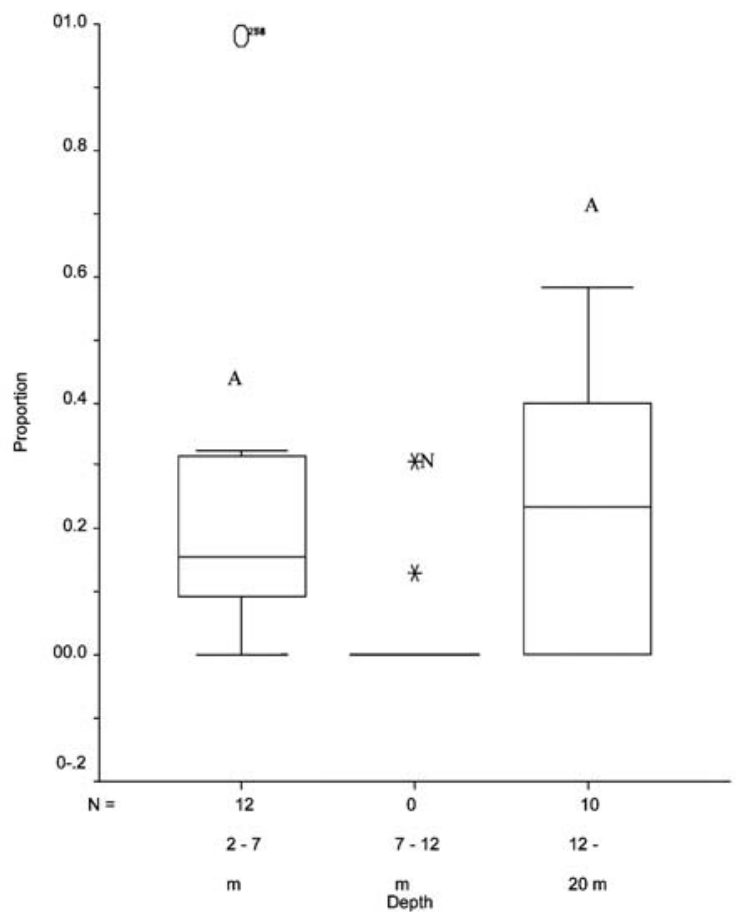

Fig. 7. Proportion of lumpy morphology of $L$. muelleri by depth. Box plots denoted by a different capital letter differ significantly by K-W test $(\mathrm{p} \leq 0.05)$ with post-hoc Dunn Test, asterisks represent the significant group. Bars represent standard deviation.

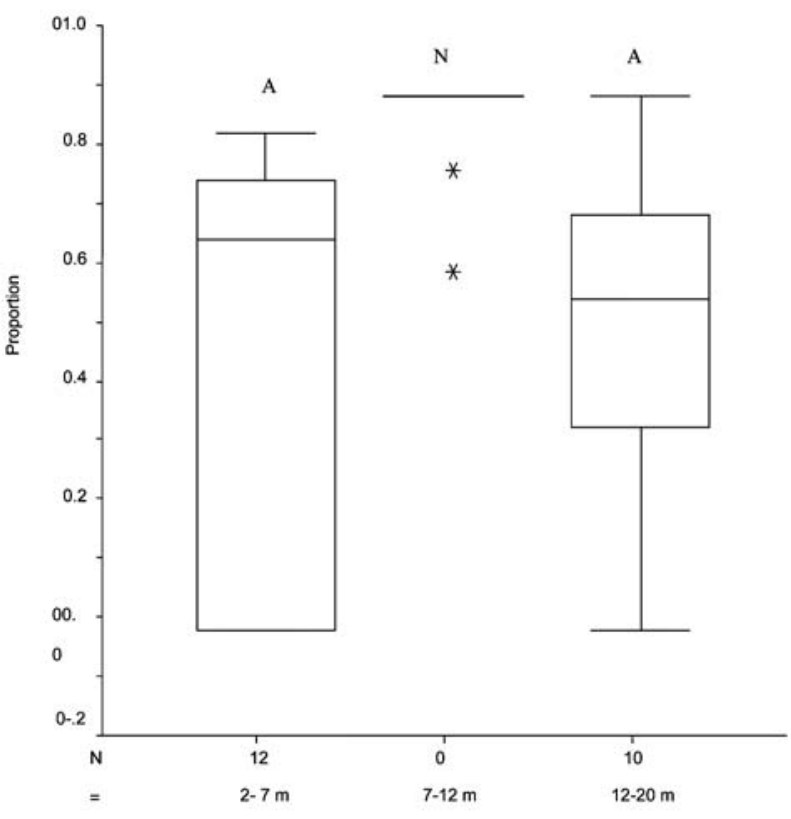

Depth

Fig. 8. Proportion of fructicose morphology of $\mathbf{L}$. muelleri by depth. Meaning of symbols and letters are the same as in Fig.4. 
the proportion found at $20 \mathrm{~m}$. The proportions of the foliose forms inversely corresponded with the proportions of the fruticose form showing significant differences between shallow beds in relation to the deeper areas (Fig. 6). The proportion of the fructifoliose form remained relatively stable between depths and no significance differences were observed (Fig. 5).

Fruticose and lumpy growth-forms were observed in L. muelleri, both were present at the extremes of the surveyed depths but not common in the middle range (Figs 7 - 8). The lumpy growth form was more widely dispersed in the deeper water (Fig. 7) where as the fruticose form was more widely dispersed in the shallow areas (Fig. 8). Comparisons of the abundance of species between the current vs. wave beds (Table 2) showed a clear distinction between the forms seen, an example of this is the restriction of Neogoniolithon trichotomum to the upper areas $(2-7 \mathrm{~m})$.

In relation to substrate type (Table 2) the dominance of Lithothamnion muelleri is clear in relation to all species, except for L. margaritae, in shallow water. The presence of Mesophyllum engelhartii in deep areas is noticeable but not significant. The absence of Neogoniolithon trichotomum is noticeable and significant in relation to the other species (Table 2). The growth form composition in each substrate type had similar trends in where blunt forms dominate rocky/sandy habitats and fruticose dominates in the sandy areas (Table 2).

\section{Discussion}

One of the major problems in working with rhodoliths and coralline algae in general is the identification of specimens to the generic or specific level. The classification within the order Corallinales has changed from the recognition of one or two families (living and fossil) in the early $20^{\text {th }}$ century to four families at the beginning of the $21^{\text {st }}$ century (Harvey et al., 2003). At the generic level, the changes have been more dramatic and a major evaluation (Woelkerling 1988) was necessary to settle many of the classical problems. Boundaries of genera and species remain a common problem best solved by regional monographs using consistent diagnostic features (Riosmena-Rodriguez et al., 1999; Harvey et al., 2003). Two of the major problems are that many growth-forms can occur in the same species (Woelkerling et al., 1993; Riosmena-Rodriguez et al., 1999) and a single rhodolith can be formed by several species (Basso, 1998).

Once taxonomic approaches are based on anatomical structures, and the evaluation of these structures is done (Riosmena-Rodríguez et al., 2007, Table 1) it is possible to understand patterns of distribution. In our study several species are present but it is the high morphologically variable $L$. margaritae show foliose, fruticose, lumpy growth forms, or combinations of them (RiosmenaRodríguez et al., 2007, Fig. 3), that dominants the sandy habitats in the southern part of the study area (Fig. 1- 3 Table 2). Similarly Phymatolithon calcareum, which also has great morphological variability, (Cabioch, 1966) is one of the dominant species with a wide bathymetric and geographic distribution, found along the Northeastern Atlantic ranging from the temperate areas (Irvine and Chamberlain, 1994), the Mediterranean (Cabioch et al., 1992) to the Canary Isles (Afonso-Carrillo and Gil-Rodriguez, 1982) and the Northeastern Pacific (Konar et al., 2006). Fruticose and lumpy morphologies have been described for Hydrolithon reinboldii (Payri, 1997), which is found widely in the Indo-Pacific. Based on the above observations, most of the species around the world range from fruticose to lumpy forms with a transition from mostly fruticose plants to more abundance of foliose plants (i.e. L. orbiculatum from British Isles). In our study the foliose plants were relative more abundant in deeper areas, supporting the early ideas of Kempf (1970).

The observed differences in depth distribution might be explained by a combination of environmental factors such as water motion (Steller and Foster, 1995); temperature/irradiance that 
might affect the growth and reproduction rate (Leukart, 1994); and the calcification rate (Payri, 1997; Payri et al., 2001). The effect of the environment on coralline algal morphology and distribution is widely recorded (Steneck and Adey, 1976; Steller and Foster, 1995). Light/temperature is highly temporal variable in the southern part of the Gulf with the major change happening around $30 \mathrm{~m}$ (Alvarez-Borrego, 1983; Caceres-Martínez et al., 1992). The growth rates for most of the species are known (Rivera et al., 2003; Steller, 2003), with M. engelhartii being the exception. The highest growth rate belongs to Neogoniolithon trichotomum, which grows $5.5 \mathrm{~mm}$ per year, followed by Lithophyllum margaritae (2.2mm per year) (Steller, 2003) and Lithothamnion muelleri $(0.87 \mathrm{~mm}$ per year) (Rivera et al., 2003). Considering growth rate alone, $N$. trichotomum should be dominant in sandy areas rather than L. margaritae and L. muelleri but the evident calcification is less in the first than in the later 2 species (this can be observed when decalcification is developed as in RiosmenaRodriguez et al., 1999) suggesting that it would be easier to break apart or suffer from physical damage. Also, when the relative density of conceptacles in each species is evaluated L. margaritae has the highest density of tetrasporangial conceptacles, mostly tetrasporangial, and in N. trichotomum conceptacles are not common at all (Riosmena-Rodriguez, pers. obs.). The lower amount calcium per individual and thus its ability to grow faster than L. muelleri and reproduce more often than $N$. trichotomum explain the higher density of $L$. margaritae in sandy habitats. The dominance of $L$. muelleri in rocky habitats can be explained by its relatively better survivability in relation to abrasion.

A similar trend can be reasoned for the dominance of the fruticose growth forms in our areas and elsewhere (Irvine and Chamberlain, 1994; Payri, 1997; this study). The fruticose form may have greater resistance to physical damage caused by water movement and better energy efficiency derived from photosynthesis than the other growth forms. The circular-oval shape of the fruticose form enables it to capture light from any angle and provides some resistant to breakage. While lumpy (coarse) or foliose (thinner) growth-forms have unequal surfaces with longer or wider sides that might be able to capture light in one direction. Foliose plants are orientated to receive light mostly from the upper layers and lose out on the scattered reflections in the superficial waters, a possible adaptation to deep areas but one that results in an increase in fragility. Lumpy plants may better adapted to rocky areas are more abundant.

\section{Acknowledgements}

We thank M.S. Foster and E. Serviere-Zaragoza for their comments on an early version and two anonymous reviewers for their suggestions to the present version. Financial support from CONABIO FB 345/B 086/94, UCAR S97-74025, National Geographic 5774-96 and Fondo CONACYT-SEMARNAT 23425 are also acknowledged.

\section{References}

Adey, W.H. and McKibbin, D.L. 1970. Studies on the Maerl species Phymatolithon calcareum (Pollas) nov. comb. and Lithothamnium coralloides Crouan in the Rio Vigo. Botanica Marina, 33, 100-106.

Afonso-Carrillo, J. and Gil-Rodríguez, M. C., 1982. Sobre la presencia de un fondo de "maërl" en las Islas Canarias. Collectanea Botanica, 13, 703-708.

Álvarez-Borrego, S. 1983. Gulf of California. In, Ecosystems of the world. Elsevier. U.S.A. pp. 427- 449.

Basso, D. 1998. Deep rhodolith distribution in the Pontian Islands, Italy: a model for the paleoecology of a temperate sea. Palaeogeography, Palaeoclimatology, Palaeoecology, 137, 173-187.

Birkett, D., Maggs, C. and Dring, M. 1998. Maerl (volume V). An overview of dynamic and sensitivity characteristics for conservation management of marine SACs. Scottish Association for Marine Science (UK Marine SACs Project).

Blunden, W., Farnham, F., Jephson, N., Fuenn, R.H. and Plunkett, B.A. 1977. The composition of Maerl from the island of Southern Brittany. Botanica Marina, 20, 121-125.

Bosence, D.W.J. 1983. The occurrence and ecology of recent rhodoliths - a review. In, Peryt, T. M. (ed) Coated 
Grains. Springer-Verlag, Berlin. pp. 225-242.

Bosence, D.W.J. 1985. The morphology and ecology of a mound-building coralline alga (Neogoniolithon strictum from the Florida Keys. Paleontology, 28, pp. 189-206.

Bosence, D. and Wilson, J. 2003. Maerl growth, carbonate production rates and accumulation rates in the northeast Atlantic. Aquatic Conservation Marine Freshwater Ecosystems, 13, S21-S31.

Cabioch, J. 1966. Contribution à l'étude morphologique, anatomique et systématique de deux Mélobésiées: Lithothamnium calcareum (Pallas) Areschoug et Lithothamnium corallioides, 9, 33-53.

Cabioch J. 1969. Les fonds de maerl de la baie de Morlaix et leur peuplement végétal. Cahiers de Biologie Marine $10,139-161$.

Cabioch, J., Floc'h, J.Y., Toquin, A.L., Boudouresque, C.F., Meinesz, A. and Verlaque, M. 1992. Guia de las Algas de los Mares de Europa: Atlantico y Mediterraneo. Omega, España. 249 pp.

Cáceres-Martínez, C., Cortés, S.J. and Chávez, V.J. 1992. Reclutamiento de juveniles de moluscos bivalos en Baja California Sur, México. In, Memorias del Taller México-Australia sobre reclutamiento de recursos bentónicos de Baja California SEPESCA-IPN, México. pp. 151-165.

Carannante, G. Esteban, Milliam, M.J.D. and Simone, L. 1988. Carbonate lithofacies as paleolatitude indicators: Problems and limitations. Sedimentary Geology, 60, 333-346.

Foster, M.S. 2001. Rhodoliths: Between rocks and soft places. Journal of Phycology, 37, 659-667.

Foster, M.S., Riosmena-Rodriguez, R., Steller, D., Woelkerling, W.J. (1997). Living rhodolith beds in the Gulf of California and their implications for paleoenvironmental interpretation. In, Johnson M.E. and LedesmaVásquez, J. (eds). Pliocene carbonates and related facies flanking the Gulf of California, Baja California, Mexico. Geological Society of America special paper no. 318.

Freiwald, A., Henrich, R., Shäfer, P. and Willkom, H. 1991. The significance of high-Boreal to Subarctic Maerl deposits in northern Norway to reconstruct Holocene climatic changes and sea level oscillations. FACIES. $25,315-340$.

Harvey, A.S., Broadwater, S.T., Woelkerling, W.J. and Mitrovski, P.J. 2003. Choreonema (Corallinales, Rhodophyta): 18S rDNA phylogeny and resurrection of the Hapalidiaceae for the subffamilies Choreonematoidea, Austrolithoideae and Melobesioidae. Journal of Phycology, 39(5), 988-998.

Keegan, B. F. 1974. The macrofauna of maerl substrates on the west coast of Ireland. Cahioers Biologie Marine, 15, 513-530.

Irvine, L.M. and Chamberlain, Y.M. 1994. Seaweeds of British Isles. Vol 1. Rhodophyta part. 2b. Corallinales, Hildenbrandiales. The natural Hystory Museum. London, England. 276 pp

Kempf, M. 1970. Notes on the benthic biometry of the N-NE Brazilian shelf. Marine Biology, 5, 213-224.

Konar, B., Riosmena-Rodríguez R. and Iken, K. 2006. Rhodolith bed: a newly discovered habitat in the North Pacific Ocean. Botanica Marina, 49, 355-359.

Leukart, P. 1994. Field and laboratory studies on depth dependence, seasonality and light requirement of growth in three species of crustose coralline algae (Corallinales, Rhodophyta). Phycologia, 33, 281-290.

Mabesone, J. M., Kempf, M. and Coutinho, N. 1972. Characterization of surface sediments on the northern and eastern Brazilian shelf. Trabajos Oceanográficos de la Universidad Federeal de Pernanbuco, 13, 41-48.

Payri, C.E. 1997. Hydrolithon reinboldii rhodolith distribution, growth and carbon production of a French Polynesian reef. Proceedings of the Eighth International Coral Reef Symposium, 1, 755-760.

Payri, C.E., Maritorena, S., Bizeau, C., Rodiere, M., 2001. Photoacclimation in the tropical coralline alga Hydrolithon onkodes (Rhodophyta, Corallinaceae) from a French Polynesian reef. Journal of Phycology, 37, 223-234.

Piller, W.E. and Rasser, M. 1996. Rhodolith formation induced by reef erosion in the Red Sea, Egypt. Coral Reefs, 15, 191-198.

Riosmena-Rodríguez, R., Woelkerling, W.J. and Foster, M.S. 1999. Taxonomic reassessment of rhodolith-forming species of Lithophyllum (Corallinales, Rhodophyta) in the Gulf of California, México. Phycologia, 38, 401417.

Riosmena-Rodríguez, R., Steller, D.L., Hinojosa-Arango, G. and Foster, M.S. 2007. Biology and Conservation of Rhodolith beds. In, Bursca, R.C. (ed.) Biodiversity and Conservation of the Sea of Cortez. University of Arizona and Arizona-Sonora Desert Museum Press.

Rivera, M.G., Riosmena-Rodríguez, R. and Foster, M.S. 2003. Age and growth of Lithothamnion muelleri (Corallinales, Rhodophyta) in the southwestern Gulf of California, México. Ciencias Marinas, 30, 235-249. 
Steller, D.L. 2003. Rhodoliths in the Gulf of California, growth, demography, disturbance and effects on population dynamics of catarina scallops. Ph.D. University of California, Santa Cruz.

Steller, D.L. and Foster, M.S. 1995. Environmental factors influencing distribution and morphology of rhodoliths in Bahía Concepción, B.C.S. Journal of Experimental Marine Biology and Ecology, 194, 201-212.

Steller, D.L., Riosmena-Rodríguez, R., Roberts, C. and Foster, M.S. 2003. Rhodolith bed diversity in the Gulf of California: The importance of rhodolith structure and consequences of anthropogenic disturbances. Aquatic conservation: Marine and freshwater ecosystems 13, S5-S20.

Steneck, R.S. and Adey, W.H. 1976. The role of environment in control of morphology in Lithophyllum congestum, a Caribbean algal ridge builder. Botanica Marina, 19, 197-215.

Woelkerling, W. J. 1988. The coralline red algae: an analysis of genera and subfamilies of nongeniculate Corallinaceae. British Museum (Natural History). Oxford University Press. U.S.A. 268 pp.

Woelkerling, W. J., Irvine, L.M. and Harvey, A.S. 1993. Growth forms in non-geniculate coralline red algae (Corallinales, Rhodophyta). Australian Systematic Botany, 6, 277-293.

Zar, J. H. 1996. Biostatistical Analisis, 3rd edition. Upper Saddle Qiver N. J. Prentice Hall International, Inc., $95 \mathrm{pp}$. 